\title{
Self-sufficiency for Plasma in Belgium
}

\begin{tabular}{|l|l|l|}
\hline C. & Vermylen \\
\hline
\end{tabular}

Belgium Red Cross Blood Transfusion Service, Leuven, Belgium

Dr. C. Vermylen, Belgium Red Cross Blood Transfusion Service, Leuven (Belgium)

Per million inhabitants, 12,000 liters of plasma are collected. To avoid wastage of red cells, 7,000 of these liters are drawn by plasmapheresis. We are able to obtain $300 \mathrm{~kg}$ albumin, 2x 106 units of factor VIII, 15,000 doses of tetanus immune globulin per million inhabitants. Besides these key-products, all other usual coagulation factors and hyperimmune gammaglobulins are easily provided by 600 unremunerated plasmapheresis donors per million inhabitants. The 6,000 plasma donors of Belgium form a real club, which differs from other altruistic services clubs like Rotary and Lions in the fact that membership is open to all social classes. 